\title{
Are Price-Based Capital Account Regulations Effective in Developing Countries?
}

\author{
Antonio C. David ${ }^{1}$ \\ adavid2@worldbank.org
}

\begin{abstract}
In this paper we evaluate the effectiveness of policy measures adopted by Chile and Colombia aiming to mitigate the deleterious effects of pro-cyclical capital flows. In the case of Chile, according to our GMM analysis, capital controls succeeded in reducing net short-term capital flows, but did not affect long-term flows. As far as Colombia is concerned, the regulations were capable of affecting total flows and also long-term ones. In addition, our co-integration models indicate that the regulations did not have a direct effect on the real exchange rate in the Chilean case. Nonetheless, the model used for Colombia did detect a direct impact of the capital controls on the real exchange rate. Therefore, our results do not seem to support the idea that those regulations were easily evaded.
\end{abstract}

JEL Classification: E60, O16, O54, F33, F34.

Keywords: Capital Flows, Capital Controls, Developing Countries.

World Bank Policy Research Working Paper 4175, March 2007

The Policy Research Working Paper Series disseminates the findings of work in progress to encourage the exchange of ideas about development issues. An objective of the series is to get the findings out quickly, even if the presentations are less than fully polished. The papers carry the names of the authors and should be cited accordingly. The findings, interpretations, and conclusions expressed in this paper are entirely those of the authors. They do not necessarily represent the view of the World Bank, its Executive Directors, or the countries they represent. Policy Research Working Papers are available online at http://econ.worldbank.org.

\footnotetext{
${ }^{1}$ Rodrigo Caputo, Edouard Challe, Carmen Li, Chris Meissner, Gabriel Palma, Daniel Oks and participants at the 4th INFINITI conference at Trinity College Dublin in June 2006 provided very useful comments. I also would like to thank Francisco Gallego, Hernan Rincon and Andre Loureiro for help with data.
} 


\section{Introduction}

The excessive liquidity in international capital markets during the 1990s posed several challenges to policymakers in emerging economies. Among numerous issues, the links between financial volatility and short-term capital flows were a particular source of concern. In addition, problems associated with moral hazard, fragility in financial intermediaries' and corporate balance sheets, asset price bubbles, consumption booms and real exchange rate overvaluation were intimately connected to the boom-bust cycle in international capital flows to developing countries following the financial liberalization process.

In this context, it became evident that full capital account openness can be associated with increased macroeconomic volatility and limitations in degrees of freedom for domestic policy makers, particularly when capital flows are strongly pro-cyclical. These facts prompted a number of countries to (re)-adopt capital account regulations. Our interest at present lies in examining the imposition of price-based capital account management polices in Chile and Colombia since the early 1990s. The aims of those regulations included reducing the costs of sterilization policies and the appreciation of the real exchange rate associated with large capital inflows and increasing the autonomy of domestic monetary policy.

This paper intends to evaluate the effectiveness of those regulations in attaining some of these goals. In particular, we will concentrate on the effects of the reserve requirements on capital flows and on the real exchange rate. This task presents several difficulties. Cordella (2003) argues that those "taxes" on inflows may either increase or decrease the supply of flows depending on two counteracting forces. On the one hand, if those policies are successful in changing the composition of external liabilities and in reducing the vulnerability to crises, they could in fact generate larger long-term capital inflows, since risk-adjusted yields may increase. On the other hand, the direct decrease in returns from investing in the country (due to the tax) and the increase in the irreversibility of the investment have a negative impact on capital inflows.

We will analyze creditor-based data at a monthly frequency that has not been used previously to evaluate the capital account regulations. There are two main advantages in using this dataset. The capital flows recorded are arguably less likely to be subject to 
evasion or re-labelling than official data from the respective central banks. The reserve requirements were imposed on the borrower's part of the transaction, hence it might be the case that there were less incentives for lenders to incorrectly report the nature of the capital account transaction with the objective of evading the controls. In addition, as far as Colombia is concerned, the official statistics on capital flows from the Balanza Cambiaria do not discriminate between flows of different maturities. Our data allow for a direct analysis of the effect of capital account regulations on the maturity structure of flows, which has proved to be difficult in the past. In any case, the analysis of a different dataset might prove to be a useful exercise in comparison with the previous literature on the subject. Nonetheless, a major drawback is that the data only encompasses capital flows from and to the United States.

The paper is divided into 5 sections. In the second section we discuss the macroeconomic environment that prevailed in Chile and Colombia during the 1990s and the capital account policies adopted. Subsequently, in section 3, we briefly survey the previous literature on the Chilean and Colombian capital controls. In the fourth section, we present evidence from Generalized Method of Moments (GMM) regressions and Vector Error Correction models (VECM) in order to assess the effects of the price-based capital controls on capital flows and on the real exchange rate. The final section presents the conclusions obtained.

\section{Capital Controls in Chile and Colombia}

The restoration of democracy in 1990 probably marked the start of the period of greatest prosperity in Chilean history. Chile’s macroeconomic performance and stable environment led the country to be granted an investment grade status by the rating agency Standard \& Poor's in 1992. In fact, it is necessary to place the Chilean price-based capital controls in a wider context. They were an integral part of a macroeconomic policy strategy that allowed Chilean authorities to sustain the crawling band exchange rate regime and target interest rates to stabilize domestic prices, while reducing the excessive pressure that those high interest rates put on the exchange rate. 
The Unremunerated Reserve Requirement (URR) on capital inflows was imposed in June 1991 at a rate of $20 \%$ with the objective of coping with the "mixed blessings" of large capital inflows. This market-based policy acted as an "asymmetric tax" (falling more heavily on short-term capital inflows) and was accompanied by other prudential measures (such as size limits on foreign bond issues by domestic intermediaries) and an extensive liberalization of capital outflows. Laban \& Larrain (2000) argue that the liberalization of outflows might encourage further capital inflows due to the reduction in the irreversibility of investing in the country. Nevertheless, it could also facilitate "runs" in bad times, which effectively occurred when domestic pension funds were responsible for large capital outflows in 1998. In any case, given the pro-cyclicality of capital flows, the latter effect seems to outweigh the former one.

A detailed description of changes in capital account regulations in Chile is presented in Appendix B. The private sector was constantly looking for ways to circumvent the controls (De Gregorio et al., 2000), while the Central Bank authorities tried to close loopholes ${ }^{\mathrm{i}}$. In 1998, in the midst of the turmoil caused by the difficulties in Russia, the unremunerated reserve requirement was reduced to $10 \%$ and, in September of that year, it was finally set to zero. Subsequently, in June 2001, the Chilean authorities decided to abolish the controls on inflows altogether.

The economic liberalization process in Colombia started in the early 1990s, when severe political and social turmoil precipitated the adoption of "structural" reforms, initially marked by the elimination of most quantitative controls on imports, followed by a gradual but rapid reduction of tariffs and the liberalization of foreign lending in February 1992. As in the Chilean case, the return of large capital inflows to the country from the early 1990s onwards marked a period of real exchange rate appreciation.

The Colombian authorities opted to move toward more flexible, price-based capital account regulations from September 1993, rather than adopting full capital account convertibility or maintaining "old-style” administrative capital controls (Appendix B presents a description of the evolution of those regulations). The rationale for the adoption of controls on capital inflows by the Colombian authorities is analogous to the reasons that were put forward by Chilean policymakers. 
The reserve requirements and minimum maturities changed frequently over the 1990s; in fact, the Colombian restrictions were far more complex than the Chilean ones and the level of the tax equivalent of the unremunerated deposits was significantly higher. This suggests that the Colombian authorities pursued a more active management policy, as far as the capital account is concerned, when compared to Chile and/or it could reflect the greater relative instability of the Colombian economy and the political strength of the export sector. In addition, the complexity of the capital controls arguably increased uncertainty and speculation, as financial market players attempted to anticipate changes in the regulations.

\section{A Survey of the Econometric Literature on the Controls on Inflows}

Nadal de Simone \& Sorsa (1999) provided an extensive review of the early econometric work on the effects of the unremunerated reserve requirements on capital flows in Chile. The studies considered by those authors presented some evidence that the URR was capable of altering the composition of capital flows towards long-term flows, but there was only mixed evidence that the URR has affected the level of total flows. Nonetheless, the econometric methodology used in most cases suffered from several shortcomings. Misspecification problems abounded (evidence of heterocedasticity, serial correlation, non-normality of the residuals, etc.) and a variety of authors failed to test for the non-stationarity of variables included in the regressions and for co-integration.

Edwards (1999) estimated a series of unrestricted VAR models and concluded that the taxes on capital flows had been unsuccessful in reducing the real exchange rate appreciation. De Gregorio et al. (2000) also considered VAR systems and found that the URR had large and significant negative effects on short-term inflows; nevertheless, it also had a positive effect on long-term inflows (and overall no effect on total flows). Their impulse response functions indicated that the URR only had transitory effects on the real exchange rate. The latter result is confirmed by Gallego et al. (2002), who estimated a two-step error-correction model for the real exchange rate, combining determinants of the equilibrium in non-traded goods markets and interest rate differentials. 
Forbes (2002) has attempted to estimate one of the possible costs of the URR. Using a Tobin's q framework and an Euler equation for a panel of Chilean publicly traded companies from 1988 to 2000, this author concluded that smaller traded firms were more financially constrained than larger firms as a consequence of the policy. This conclusion has been confirmed by a study by Gallego \& Hernandez (2003) on the microeconomic effects of the controls, which examined the financial statements of 73 Chilean firms from 1986 to 2001. One has to acknowledge that it is evident that the URR had its costs; nonetheless, those studies do not consider that it was precisely the objective of the policy to limit the access to foreign finance (i.e. the exposure) of firms that are more likely to have unhedged foreign currency debt and are more financially fragile (subject to bankruptcy from capital flow reversals or sudden stops). Smaller firms are more likely to fall into those categories.

The econometric literature on the Colombian capital account regulations has focused its attention on their impact on the level and composition of net capital inflows and, to a smaller extent, on the effect of the regulations on the real exchange rate and domestic interest rates. In addition to the usual technical econometric difficulties in analyzing those issues, in the Colombian case, the shortcomings of the empirical analysis are compounded by the lack of appropriate high frequency balance of payments statistics covering the period during which the controls were in place.

Cardenas and Barrera (1997), using data from 1985 to 1996, analyzed the effectiveness of the controls in terms of their impact on the level and composition of capital flows. They estimated simple OLS regressions for capital flows to Colombia on a proxy of the external environment, interest rate differentials, fundamentals and measures of the tax equivalent of the deposit requirements and found that the URR has been successful in tilting the maturity structure of inflows towards long-term flows, but did not reduce the total volume of capital flows. Cardenas and Steiner (2000) updated the data set that was used by Cardenas and Barreras and they ran a simple Chow test to determine if the reserve requirements changed the composition of inflows in favor of long-term flows and concluded that the deposit requirements were effective in doing so.

Ocampo and Tovar (1999) used Vector Error-Correction and State-Space models to estimate the effects of the deposit requirements on capital flows and found that the price- 
based controls were effective in reducing the total volume of capital inflows. Rincon (1999) used monthly data from September 1993 to June 1998 on net flows of short-term capital to the private sector from the foreign exchange balance and from the "cuentas de compensacion" in order to assess the effects of the capital controls and concluded that the controls were effective in reducing short-term capital inflows.

Rincon \& Villar (2000) performed an indirect test for the effect of the URR on the real exchange rate, using a single equation co-integration procedure (Engle-Granger) to determine the behavior of the latter variable. They concluded that, since capital flows affected the behavior of the real exchange rate, the URR had a significant indirect impact on that variable.

To sum up, the econometric literature on the capital controls in Chile seems to present rather positive results on the effectiveness of the deposit requirements in terms of reducing short-term inflows and increasing monetary policy autonomy. Nonetheless, the results concerning the effects of capital controls on the real exchange rate and on total capital flows are inconclusive so far. In the Colombian case, there is evidence of the effectiveness of the controls in reducing the total volume of flows. The econometric analysis of the impact of the URR on the maturity structure of flows is hampered by the lack of high frequency data distinguishing short-term from medium and long-term flows.

\section{Data, Econometric Specifications and Results}

The sources and definitions for the variables used in the empirical part are described in Appendix C. The data on capital flows at a monthly frequency employed in this study refers to bilateral capital flows between the U.S. and the two countries (including bond, equity, bank loans and other securities, as detailed below) compiled by the U.S. Treasury Department in its international capital reports (TIC) system ${ }^{\text {ii }}$. Information is collected from commercial banks and other depository institutions, bank holding companies, securities brokers and dealers, and non-banking enterprises in the United States, including the U.S. branches, agencies and subsidiaries of foreign-based banks and business enterprises. 
These data constitute an alternative creditor-based source that allows us to discriminate between flows of different maturities. In the TIC dataset, long-term securities refer to securities with an original maturity of more than one year. Short-term capital flows compiled in the TIC system include liabilities and claims arising from deposits due to or from foreign entities, financial instruments with an original maturity of one year or less, borrowings from foreigners and loans and other credits to foreigners ${ }^{\mathrm{iii}}$. As we pointed out previously, for Colombia the balanza cambiaria does not provide information on the maturity structure of flows, which renders the analysis of the effect of the controls on the maturity of capital flows particularly difficult.

A crucial question, when assessing the impact of the price-based regulations on inflows, is the appropriate measurement of the tax-equivalent of the reserve requirement. A "naïve" measure of this tax, which is constructed by combining an arbitrage condition and the uncovered interest parity equation, is widely used in the literature. Consider the case where the maturity of the loan (capital inflow) $k$ is larger than the holding period of the deposit requirement $(h)$. Assuming that the exchange rate is fixed, the uncovered interest parity would take the form:

$$
(1+i)=\left(1+i^{*}\right)+\delta
$$

Where $i$ is the domestic interest rate, $i^{*}$ is the international interest rate and $\delta$ is the tax equivalent of the reserve requirement. The following arbitrage equation is also used: $(1-u)(1+i)^{k}+u\left(1+E\left[\max \left(i, i^{*}\right)\right]\right)^{k-h}=\left(1+i^{*}\right)^{k}$

where $u$ is the unremunerated reserve requirement. The above expression simply states that the return from investing in Chile/Colombia (considering the reserve requirements) has to be equal to the return obtained from investing abroad, i.e. the international interest rate (opportunity cost). Using the UIP condition to substitute for domestic interest rates and using the approximation that $(1+j)^{x} \cong(1+x j)$ for a small $j$, we can derive the usual naïve equation for the tax equivalent: $\delta=\frac{u}{(1-u)} \frac{h}{k} i^{*}$

Note that the tax-equivalent is inversely related to the maturity of the capital inflow $(k)^{\text {iv }}$. This measure of the tax equivalent does not take the country risk premium into 
account and does not consider variations in the exchange rate. In our analysis, we will adopt a measure of the tax-equivalent cost that incorporates those factors. Firstly, we will consider the case where the holding period of the deposit $(h)$ is equal to the maturity of the loan $(k)$. The UIP condition at present is given by:

$(1+i)=\left(1+i^{*}\right)(1+\lambda)\left(1+\Delta S^{e}\right)(1+\delta)$

where $\lambda$ is the country risk premium and $\Delta S^{e}$ is the expected change in the exchange rate. The arbitrage condition is given by:

$$
\left[\left(1+i^{*}\right)(1+\lambda)\left(1+\Delta S^{e}\right)\right]^{k}=(1-u)(1+i)^{k}+u\left(1+\Delta S^{e}\right)^{h}
$$

where the term of the left-hand side is the opportunity cost of the investment decision (foreign interest rate plus country and currency risk), the first term on the right-hand side represents the returns on the amount actually invested (i.e. minus the reserve requirements) and the second term represents possible capital gains (or losses) from changes in the exchange rate. By manipulating those two equations we can obtain the following result:

$$
(1+\delta)=\frac{1}{\left(1+i^{*}\right)(1+\lambda)\left(1+\Delta S^{e}\right)}\left\{\frac{1}{1-u}\left[\left[\left(1+i^{*}\right)(1+\lambda)\left(1+\Delta S^{e}\right)\right]^{k}-u\left(1+\Delta S^{e}\right)^{h}\right]\right\}^{\frac{1}{k}}
$$

Note that the same formula is valid for the case when the holding period of the deposit requirement is larger than the maturity of the loan, i.e. the case where $h>k$. This occurs because the arbitrage condition is:

$\left[\left(1+i^{*}\right)(1+\lambda)\left(1+\Delta S^{e}\right)\right]^{h}=(1-u)(1+i)^{k}+u\left(1+\Delta S^{e}\right)^{h}$

By manipulating this expression we obtain:

$$
(1+\delta)=\frac{1}{\left(1+i^{*}\right)(1+\lambda)\left(1+\Delta S^{e}\right)}\left\{\frac{1}{1-u}\left[\left[\left(1+i^{*}\right)(1+\lambda)\left(1+\Delta S^{e}\right)\right]^{h}-u\left(1+\Delta S^{e}\right)^{h}\right]\right\}^{\frac{1}{k}}
$$

Now we will proceed to calculating the tax equivalent when $h<k$ i.e. when the maturity of the investment is larger than the holding period of the reserve requirement. If we assume that the proceeds of the deposit requirement are reinvested abroad, the arbitrage condition becomes:

$\left[\left(1+i^{*}\right)(1+\lambda)\left(1+\Delta S^{e}\right)\right]^{k}=(1-u)(1+i)^{k}+u\left[\left(1+\Delta S^{e}\right)^{h}\left(1+i^{*}\right)^{k-h}\right]$ 
By manipulating this we obtain:

$$
(1+\delta)=\frac{1}{\left(1+i^{*}\right)(1+\lambda)\left(1+\Delta S^{e}\right)}\left\{\frac{1}{1-u}\left[\left[\left(1+i^{*}\right)(1+\lambda)\left(1+\Delta S^{e}\right)\right]^{k}-u\left[\left(1+\Delta S^{e}\right)^{h}\left(1+i^{*}\right)^{k-h}\right]\right\}^{\frac{1}{k}}\right.
$$

Evidently, those measures only constitute a proxy for the costs of the reserve requirements and depend on a certain number of restrictive assumptions. In the empirical implementations, we decided to use an average of the tax equivalent variable for different maturities and we experimented with different measures for the expected rate of exchange rate depreciation (or appreciation) ${ }^{\mathrm{v}}$.

The theoretical foundations of the regressions estimated in this section can be found in the models of capital flows to developing countries surveyed in Fitzgerald (2002) and Mody \& Taylor (2002). We included variables identified as important in the literature on the determinants of capital flows focusing on push and pull factors (Agenor \& Montiel, 1999), such as domestic and foreign interest rates. In addition, we tried to capture the important role of information asymmetries in determining capital flows by including the U.S. junk bond spread in the regressions following (Mody \& Taylor, 2002). In fact, those authors argue that the high yield spread is important in explaining the supply of flows to emerging markets, partly because default risk in the U.S. could be correlated to default risk in emerging markets, but also because the empirical evidence shows that a rise in the high-yield spread is capable of predicting a slowdown in real economic activity, which is consistent with financial accelerator models (Gertler \& Lown, 1999). This predicted slowdown in economic activity could lead to a reduction in net capital flows.

Moreover, and from the viewpoint of micro level portfolio choice, Fitzgerald (2002) argues that the high yield spread may capture endogenous cycles in foreign investor's risk tendencies. We also introduce lags of capital flows as an explanatory variable with the objective of capturing herding, inertia or bandwagon effects that may arise in international capital markets in the face of asymmetric information and bounded rationality.

It is clear that endogeneity problems are likely to arise in the estimation of equations describing capital flows. In addition, right-hand-side variables are also measured with error. In this context, it is likely that the residuals of the regression will be correlated with 
the explanatory variables, which implies that OLS estimates would be biased and inconsistent. We will tackle this problem by estimating regressions using the Generalized Method of Moments (GMM) technique. In order to apply this technique, it is necessary to impose orthogonality conditions between the explanatory variables and the error term.

Note that GMM is a robust estimator and does not require assumptions about the exact distribution of data generating process (unlike Maximum Likelihood estimators). When implementing our GMM models we correct for heterocedasticity and autocorrelation of unknown form by using Andrews weights to ensure that the variancecovariance matrix estimated is positive definite. In addition, we use the J-statistic obtained from the regressions to test for the validity of the overidentifying restrictions imposed, in order to ensure that the instruments used are adequate.

\subsection{The Effect of the Reserve Requirements on Capital Inflows}

The central question that most of the empirical literature on the effects of the reserve requirements attempts to address is their direct effects on net capital inflows. We will try to tackle this issue by estimating log-linear models for capital flows as a function of the interest rate differential, the junk bond spread and the tax equivalent of the reserve requirements. The models are estimated over the period from January 1991 to December $2000^{\mathrm{vi}}$. The unit root tests for the variables included in the model (presented in Appendix A) reveal that most of the series are stationary with the exception of net short-term inflows, the terms of trade and the tax equivalent of the reserve requirements.

Hence, we will focus on net total and net long-term capital flows, as those series seem to be the ones for which we can be fairly certain that a unit root is not present and therefore the application of the GMM technique is adequate. Furthermore, following a strand of the literature on capital flows (Agenor et al. 2002); we include the interest differential, the junk bond spread and the tax equivalent series in first differences. We justify this choice for two reasons. The first one relates to the need to get rid of unit root problems. In addition, since we are dealing with capital flows, it is intuitive that changes in those series are more relevant than simply looking at the levels. Hence, we estimate the following functional form (using the same notation as in previous sections), where $\kappa$ is 
$\log$ of net capital flows, $c$ is the constant, $\omega$ is the interest differential, $\phi$ is the junk bond spread and $\varepsilon$ is the random error term.

$$
\kappa_{t}=c+\beta_{1} \kappa_{t-1}+\beta_{2} \Delta \ln (1+\omega)_{t}+\beta_{3} \Delta \ln (1+\delta)_{t}+\beta_{4} \Delta \ln (1+\phi)_{t}+\varepsilon_{t}
$$

The results obtained for the regression of net total capital flows to Chile are presented in Table 1. We used lags of net total flows, lags of the reserve requirement, lags of the interest rate differential, lags of the real exchange rate gap (cyclical component of the real exchange rate), the log of world oil prices, changes in the log of the terms of trade, the trade balance and lags of changes in the high-yield spread as instruments.

The estimates obtained are autocorrelation and heterocedasticity consistent. The relatively high R-square indicates a good fit. The J-test statistic does not reject the validity of the instruments. There is evidence of non-normality of the residuals, but as we mentioned before this is not preoccupying in the GMM framework. Most coefficients are significant at conventional levels and present the expected signs. Furthermore, the model suggests that total net capital flows are highly responsive to changes in the URR. Since the model is specified in logs, estimated coefficients can be interpreted as elasticities; hence it seems that one unit increases in the tax equivalent would reduce capital flows by $40 \%$ in this case. One should also note that a one-off shock to the first difference of the tax rate is equal to a permanent shock to the level of the tax rate.

Subsequently, we build a similar model for net long-term capital inflows to Chile, including the same explanatory variables and similar instruments as in the previous case. Once again, the J-test confirms the validity of the instruments. We found that the URR had no significant effect on net long-term capital flows, which is not surprising, since those flows were not the main target of the Chilean authorities.

Hence, our results differ from the ones obtained by De Gregorio et al. (2000), who found that the URR actually increased long-term flows. They also differ from the conclusions reached by Lefort and Lehman (2000), who found that the URR decreased net long-term capital flows. This could be explained not only by the different dataset and tax equivalent measures used in our regressions, but also by the small sample size in the Le fort and Lehman paper and the fact that both studies are subject to misspecification problems (neither paper presents the relevant tests). In addition, both papers seem to 
consider measures of long-term capital flows that include FDI, which was actually exempt from the controls, whereas our measure explicitly excludes this type of flows.

We chose to estimate a similar model for capital flows to Colombia to facilitate the comparative analysis of the experience of the two countries. Table 3 presents the results of the estimation of the model for total net capital flows to Colombia for the period from January 1993 to December 2000 ${ }^{\text {vii }}$. Furthermore, we included lags of net capital flows, lags of the interest differential, lags of the tax equivalent of the reserve requirements, lags of the real exchange rate gap, lags of the high-yield spread, World oil prices and lags of the trade balance as instruments.

The J-test does not reject the validity of the instruments. As in the Chilean case, the model suggests that total net capital flows were reduced by the reserve requirements. Nonetheless, it is interesting to note that the estimated elasticity is much smaller in the Colombian case (-7.47), indicating that flows were less sensitive to changes in the tax.

The results for the estimation of the model for net long-term capital inflows to Colombia are presented in Table 4. The URR coefficient has the expected negative sign and is of approximately the same size as the URR coefficient in the equation for total net capital flows. It is also of interest to note that the interest rate differential term does not seem to help to explain long-term capital flows to Colombia, which probably reflects the fact that those flows are determined by factors such as institutional quality rather than simple market return differentials.

Hence, we may conclude that, contrary to the Chilean case, the Colombian controls on capital inflows did have an effect on long-term capital flows. This can arguably be explained by the fact that the Colombian "tax rates" were also applied to medium-term flows. In fact, one has to bear in mind that our dataset classifies capital flows as longterm when their maturity exceeds one year. Nonetheless, at several points in time, the Colombian authorities imposed high reserve requirements on capital inflows with maturities of 1.5 to 2 years. Moreover, the results indicate total capital flows to Colombia were much less sensitive to changes in the tax rate when compared to capital flows to Chile. 


\subsection{The Effect of the URR on the Real Exchange Rate}

The Chilean and Colombian authorities were concerned with the excessive appreciation of the real exchange rate that was associated with the surge in capital inflows of the 1990s and one of the objectives of the reserve requirements was to counter this tendency. Apart from the indirect effect of the URR on the real exchange rate through the reduction of capital inflows, one also has to consider the possible impact of the capital controls on expectations about the future exchange rate (and hence on the current exchange rate).

In order to assess the effects of the URR on the real exchange rate, we decided to use the Full Information Maximum Likelihood (FIML) procedure proposed by (Pesaran et al., 2000) to analyze long-run co-integration relationships in a multivariate framework: through a vector error correction model (VECM) ${ }^{\text {viii }}$. There are a number of preliminary issues that have to be addressed when using this approach for the modelling of long-run relationships. One fundamental problem is to make sure that all the variables that are included in the long-run co-integration relationship(s) are in fact non-stationary. Another crucial step is to model appropriately deterministic components (such as trends and intercepts) and whether to include I(1) and I(0) exogenous variables.

In case exogenous variables are included in the model, the usual critical values for cointegration tests have to be changed (the appropriate critical values were tabulated by Pesaran et al. ibid.). The final preliminary problem to be resolved is the selection of the lag-order of the underlying VAR model. Too many lags may lead to overparametrisation and two few to omitted variables and autocorrelation of the residuals.

In the case of Chile, we estimate a model with a vector of $z$ random variables as specified below, partitioned between endogenous and exogenous variables. The log level of the real exchange rate, the log of the terms of trade, the level of the tax equivalent, the ratio of government spending to GDP and the log of net foreign assets were considered as endogenous variables. We have also included the log of world oil prices and a dummy variable taking the value of 1 after September $1999^{\mathrm{ix}}$ as exogenous variables. Hence, the model is specified as follows: the first two terms on the right-hand-side of the expression 
represent deterministic components, $\Gamma_{i}$ are short-run response matrices and $\Pi$ is the long-run multiplier matrix.

$$
\Delta z_{t}=a_{0}+a_{1} t+\sum_{i=1}^{p-1} \Gamma_{i} \Delta z_{t-i}+\Pi z_{t-1}+e_{t}
$$

Unit root tests for the variables are presented in Appendix A and indicate that the series included are non-stationary. After visual inspection of the series included, we estimated a model with unrestricted intercept and restricted trends, the Akaike information criterion suggests a model with two lags for that specification. Both the trace and maximum-eigenvalue statistics indicate only one co-integrating vector involving the variables considered above ${ }^{\mathrm{x}}$. Table 5 presents the maximum likelihood estimates for the co-integrating vector, where we normalized the coefficient of the real exchange rate to 1 in order to identify the co-integration relationship. We decided to impose restrictions on the coefficients and test those sequentially following the procedure suggested by Pesaran et al. (2000).

The coefficient for the tax equivalent of the reserve requirement turned out to be insignificant, as evidenced by the likelihood ratio test (LR test statistic of 0.003 and pvalue of 0.96). Hence, it seems that the URR did not have a direct long run effect on the real exchange rate in Chile, i.e. it was not capable of preventing the appreciation of the real exchange in the long run beyond the indirect effect through the reduction in net total capital inflows. We now examine the short-term dynamics of the model, by specifying an error correction model (Table 6). The relatively small coefficient of the error correction term suggests a slow adjustment towards equilibrium. There is no evidence of nonnormality of the residuals and heterocedasticity, but there is some evidence of serial correlation; therefore, we present Newey-West corrected standard errors.

The results indicate that the tax equivalent also failed to have a direct short-run effect on the real exchange rate. Note that this evidence only refers to direct effects not capturing the indirect effect of the URR on the real exchange rate through the reduction of capital flows.

We estimated a similar model for Colombia including the log of the terms of trade, the log of net foreign assets and the log of real government expenditures as endogenous variables. In the context of a model with unrestricted intercepts and restricted trend and 
three lags, as indicated by the Akaike Information Criterion (AIC), both the trace and maximum-eigenvalue statistics indicate only one co-integrating vector ${ }^{\mathrm{xi}}$.

Maximum-likelihood estimates of the long-run parameters are shown in Table 7. Contrary to the Chilean case, the likelihood ratio test for over-identifying restrictions strongly rejects the null of a zero long-run coefficient for the tax equivalent at conventional significance levels (test statistic of 23.55). In addition to being statistically significant, the coefficient of the URR has the correct sign, indicating that changes in the URR had a direct effect towards a depreciation of the real exchange rate. Therefore, the URR seems to affect directly the real exchange rate in the long run, in the Colombian case, arguably contributing toward mitigating the real exchange rate appreciation verified until the late 1990s.

If we consider the short-run dynamics as characterised by the error-correction model presented in Table 8 (only statistically significant variables are presented), the direct effect of the tax equivalent on the real exchange rate is not apparent. Nonetheless, it has to be noted that the model presents evidence of non-normal residuals, therefore indicating some form of misspecification, despite the fact that heterocedasticity and autocorrelation seem to be ruled out by the standard tests. The fact that URR had an impact on the real exchange rate in Colombia, but not in Chile might suggest that markets did not perceive capital controls in this country to be anti-cyclical and therefore merely temporary. 


\section{Conclusion}

According to our results, there is evidence that the controls on capital inflows reduced total net capital flows in the case of Chile; nevertheless, they do not seem to have affected long-term capital flows in this country. We can reject the claims found in part of the literature that the URR actually increased long-term flows, while confirming the improvement in the maturity structure of external debt.

The empirical evidence for Colombia suggests that the regulations have reduced both long-term and total flows. This result is particularly interesting as the dataset used for the analysis allows for the disaggregation of capital inflows according to their maturity, which was a major difficulty faced by the previous literature on the Colombian controls. In addition, the results indicate that capital flows to Colombia were less sensitive to changes in the tax rate than capital flows to Chile.

Our co-integration models for real exchange rates showed that, in the case of Chile, the URR did not have a direct effect on the real exchange rate either in the long run or in the short run. Therefore, the controls on inflows only contributed towards reducing an excessive real exchange rate appreciation indirectly, through their effect on total net capital inflows. The co-integration model used for Colombia did detect a direct impact of the capital account regulations on the real exchange rate, in the long run, thus suggesting that the taxes on inflows did directly reduce the appreciation of the real exchange rate.

Thus, the results presented in this paper seem to reject claims that price-based capital account regulations were easily circumvented by market players and therefore were non-binding. Our distinct dataset and arguably more appropriate econometric techniques indicated that the capital account policies analyzed seem to have had significant macroeconomic effects on the countries studied.

Evidently, this does not mean that the relevant authorities applied those policies optimally. In fact, a number of authors have emphasized failures of policymakers in the two countries to alter the capital controls when it was necessary to do so (see David, 2005 for related criticisms). As an avenue for further research on the topic, one could also consider whether resorting to prudential regulations applicable to financial institutions or 
corporations rather than regulating capital flows, would reduce some of the costs of such policies, while achieving similar benefits.

\section{REFERENCES}

Agenor, P.R. \& Montiel, P. (1999) “Development Macroeconomics” 2nd Edition NJ: Princeton University Press.

Agénor, P.R., et al. (2002) "Cyclical fluctuations in Brazil's real exchange rate: the role of domestic and external factors (1988-95)” Revista Brasileira de Economia, Jan-Mar, Vol.56, No.1, pp.47-74

Bennett, H. \& Valdes, R. (2001) "Series de terminos de intercambio de frecuencia mensual para la economia chilena: 1965-1999.” Working Paper 96, May. Santiago: Central Bank of Chile.

Cardenas, M.; Barrera, F. (1997) “On the Effectiveness of Capital Controls: The Experience of Colombia during the 1990s" Journal-of-Development-Economics; 54(1), October, pages 27-57.

Cardenas, M. \& Steiner, R. (2000) “Private Capital Flows in Colombia” in Larrain, F. B. (ed.) Capital Flows, Capital Controls \& Currency Crises: Latin America in the 1990s” Ann Arbor: University of Michigan Press.

Cordella, T. (2003) “Can Short-term Capital Controls promote Capital Inflows?” Journal of International Money and Finance, 22, p.737-745.

David, A. C. (2005) "Do Controls on Capital Inflows Insulate Domestic Variables Against External Shocks?”, Faculty of Economics, University of Cambridge, U.K, mimeo.

De Gregorio, J., Edwards, S. \& Valdes, R.O. (2000) “Controls on Capital Flows: Do they Work?” NBER Working Paper 7645, April, Cambridge: MA.

Edwards, S. (1999) “How effective are Capital Controls?” NBER Working Paper 7413, November, Cambridge: MA.

Fitzgerald, V. (2002) “The Instability of the Emerging markets Asset Demand Schedule” UNU/WIDER Discussion Paper DP2002/80, September.

Forbes, K. (2002) "One Cost of the Chilean Capital Controls: Increased Financial Constraints for Smaller Traded Firms” MIT/Sloan Working Paper: 4273-02, December. 
Gallego, F. Et al. (2002) “Capital Controls in Chile: Were they Effective?” in Hernandez, L. \& Schmidt-Hebbel eds. Banking, Financial Integration and International Crises. Santiago de Chile: Central Bank of Chile.

Gallego, F. \& Hernandez, L. (2003) "Microeconomic Effects of Capital Controls: The Chilean Experience During the 1990s" Central Bank of Chile Working papers: 203, February.

Gertler, M. \& Lown, C. (1999) "The information in the High-Yield Bond Spread for the Business Cycle: Evidence and Some Implications”. Oxford Review of Economic Policy, Vol.15, No.3, pp.132-150.

Laban, R.M. \& Larrain, F.B. (2000) "Private Capital Flows to Chile in the 1990s: Causes, Effects, and Policy Reactions” in Larrain, F. B. (ed.) Capital Flows, Capital Controls \& Currency Crises: Latin America in the 1990s” Ann Arbor: University of Michigan Press.

Le Fort, G. \& Lehmann, S. (2000) "Choques Externos, Gasto Agregado, Cuenta de Capitales y Encaje: Hechos Estilizados” Unpublished Manuscript, Banco Central de Chile.

Mody, A. \& Taylor, M.P. (2002) "International Capital Crunches: The time-varying Role of Informational Asymmetries” IMF Working Paper 43 February, Washington: DC.

Nadal-De Simone, F. \& Sorsa, P. (1999) “A Review of Capital Account Restrictions in Chile in the 1990s” IMF Working Paper, April, Washington DC.

Ocampo, J.A. \& Tovar, C.E. (1999) "Price-Based Capital Account Regulations: The Colombian Experience” Financiamiento del Desarollo Series, no 87, ECLAC, Santiago: Chile.

Pesaran et al. (2000) "Structural Analysis of Vector Error Correction Models with Exogenous I(1) Variables” Journal of Econometrics, Vol. 97, pp. 293-343.

Rincon, H. (1999) "Efectividad del Control a los Flujos de Capital" Borradores de Economia n ${ }^{0} 120$ Banco de la Republica. Bogota: Colombia.

Rincon, H. \& Villar, L. (2000) "The Colombian Economy in the 1990s : Capital Flows and Foreign Exchange Regimes” Borradores de Economia n ${ }^{\circ} 149$ Banco de la Republica. Bogota: Colombia. 
Table 1

GMM Estimation of Total Net Capital Flows to Chile (1991-2000)

\begin{tabular}{|c|c|c|c|c|}
\hline Variable & $\begin{array}{l}\text { Coefficient } \\
\text { [P-values] }\end{array}$ & R-squared & J-Test & Normality \\
\hline 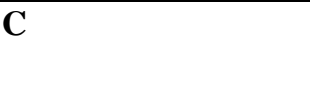 & $\begin{array}{c}0.204 \\
{[0.00]}\end{array}$ & 0.242 & $\begin{array}{c}0.175 \\
{[0.46]}\end{array}$ & $\begin{array}{c}14.960 \\
{[0.00]}\end{array}$ \\
\hline (Capital Flows) $_{\mathrm{t}-1}$ & $\begin{array}{c}0.407 \\
{[0.00]}\end{array}$ & & & \\
\hline Interest Differential & $\begin{array}{l}13.460 \\
{[0.00]}\end{array}$ & & & \\
\hline Tax Equivalent & $\begin{array}{c}-41.834 \\
{[0.01]}\end{array}$ & & & \\
\hline High-Yield Spread & $\begin{array}{l}-0.182 \\
{[0.99]}\end{array}$ & & & \\
\hline
\end{tabular}

J-statistic refers to the test for the validity of instruments included for the estimation of the model. Normality refers to the Jarque-Bera test for the normality of the residuals in the regression. $P$-values for all the test statistics are presented in brackets.

Table 2

GMM Estimation of Net Long-Term Capital Flows to Chile (1991-2000)

\begin{tabular}{|c|c|c|c|c|}
\hline Variable & $\begin{array}{c}\text { Coefficient } \\
\text { [P-values] }\end{array}$ & R-squared & J-Test & Normality \\
\hline C & $\begin{array}{l}-0.032 \\
{[0.37]}\end{array}$ & 0.125 & $\begin{array}{c}0.156 \\
{[0.60]}\end{array}$ & $\begin{array}{r}31.232 \\
{[0.00]}\end{array}$ \\
\hline$(\text { Capital Flows) })_{t-1}$ & $\begin{array}{c}0.221 \\
{[0.00]}\end{array}$ & & & \\
\hline Interest Differential & $\begin{array}{l}10.745 \\
{[0.00]}\end{array}$ & & & \\
\hline Tax Equivalent & $\begin{array}{c}-24.768 \\
{[0.26]}\end{array}$ & & & \\
\hline High-Yield Spread & $\begin{array}{l}-2.385 \\
{[0.88]}\end{array}$ & & & \\
\hline
\end{tabular}

J-statistic refers to the test for the validity of instruments included for the estimation of the model. Normality refers to the Jarque-Bera test for the normality of the residuals in the regression. P-values for all the test statistics are presented in brackets. 
Table 3

GMM Estimation of Total Net Capital Flows to Colombia (1993-2000)

\begin{tabular}{|c|c|c|c|c|}
\hline Variable & $\begin{array}{c}\text { Coefficient } \\
\text { [P-values] }\end{array}$ & R-squared & J-Test & Normality \\
\hline 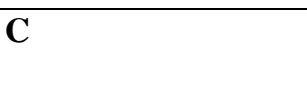 & $\begin{array}{l}0.058 \\
{[0.19]}\end{array}$ & 0.133 & $\begin{array}{c}0.217 \\
{[0.47]}\end{array}$ & $\begin{array}{c}32.310 \\
{[0.00]}\end{array}$ \\
\hline$(\text { Capital Flows })_{t-1}$ & $\begin{array}{c}0.648 \\
{[0.00]}\end{array}$ & & & \\
\hline Interest Differential & $\begin{array}{c}0.594 \\
{[0.83]}\end{array}$ & & & \\
\hline Tax Equivalent & $\begin{array}{l}-7.472 \\
{[0.00]}\end{array}$ & & & \\
\hline High Yield Spread & $\begin{array}{c}-46.961 \\
{[0.26]} \\
\end{array}$ & & & \\
\hline
\end{tabular}

J-statistic refers to the test for the validity of instruments included for the estimation of the model. Normality refers to the Jarque-Bera test for the normality of the residuals in the regression. P-values for all the test statistics are presented in brackets.

\section{Table 4}

GMM Estimation of Net Long Term Capital Flows to Colombia (1993-2000)

\begin{tabular}{|c|c|c|c|c|}
\hline Variable & $\begin{array}{l}\text { Coefficient } \\
\text { [P-values] }\end{array}$ & R-squared & J-Test & Normality \\
\hline $\bar{C}$ & $\begin{array}{l}-0.094 \\
{[0.00]}\end{array}$ & 0.061 & $\begin{array}{c}0.160 \\
{[0.80]}\end{array}$ & $\begin{array}{r}36.962 \\
{[0.00]}\end{array}$ \\
\hline$(\text { Capital Flows })_{t-1}$ & $\begin{array}{c}0.294 \\
{[0.00]}\end{array}$ & & & \\
\hline Interest Differential & $\begin{array}{l}-0.037 \\
{[0.98]}\end{array}$ & & & \\
\hline Tax Equivalent & $\begin{array}{l}-8.299 \\
{[0.00]}\end{array}$ & & & \\
\hline High Yield Spread & $\begin{array}{r}-0.740 \\
{[0.98]}\end{array}$ & & & \\
\hline
\end{tabular}

J-statistic refers to the test for the validity of instruments included for the estimation of the model. Normality refers to the Jarque-Bera test for the normality of the residuals in the regression. P-values for all the test statistics are presented in brackets. 
Table 5

\begin{tabular}{cc}
\multicolumn{2}{c}{ Co-integration Vector } \\
\hline \\
Coefficients \\
[Standard Errors]
\end{tabular}

\begin{tabular}{cc}
\hline Overidentifying Restrictions & LR Statistic 0.003 \\
[p-value 0.96]
\end{tabular}

Note: Overidentifying restriction of Zero Long-Run

Coefficient on the Reserve Requirement was imposed.

\section{Table 6}

Error-Correction Model for Chilean Real Exchange Rate (1991-2000)

\begin{tabular}{|c|c|c|c|c|c|}
\hline Variable & $\begin{array}{l}\text { Coefficient } \\
\text { [P-values] }\end{array}$ & R-squared & $\overline{\mathbf{L M}}$ & White & Normality \\
\hline & & 0.297 & $\begin{array}{l}22.026 \\
{[0.03]}\end{array}$ & $\begin{array}{l}0.075 \\
{[0.78]}\end{array}$ & $\begin{array}{l}3.083 \\
{[0.21]}\end{array}$ \\
\hline Intercept & $\begin{array}{c}0.891 \\
{[0.00]}\end{array}$ & & & & \\
\hline$\Delta(\text { Real Exchange Rate })_{t-1}$ & $\begin{array}{l}0.469 \\
{[0.00]}\end{array}$ & & & & \\
\hline$\Delta(\text { Tax Equivalent })_{t-1}$ & $\begin{array}{l}0.048 \\
{[0.66]}\end{array}$ & & & & \\
\hline$\Delta(\text { Net Foreign Asset })_{t-1}$ & $\begin{array}{l}0.118 \\
{[0.01]}\end{array}$ & & & & \\
\hline Error Correction Term & $\begin{array}{l}-0.114 \\
{[0.00]}\end{array}$ & & & & \\
\hline World Oil Prices & $\begin{array}{l}-0.016 \\
{[0.05]}\end{array}$ & & & & \\
\hline Dummy 1999 & $\begin{array}{l}0.023 \\
{[0.00]}\end{array}$ & & & & \\
\hline
\end{tabular}

LM refers to the Lagrange Multiplier test for serial correlation of the residuals of the model, White represents the White test for heterocedasticity of the residuals, Normality is the Jarque-Bera test for the normality of the residuals in the regression. P-values for all the test statistics are presented in brackets. The dummy variable was included to capture the end of the crawling band regime in September 1999. 


\section{Table 7}

Co-integration Vector

\begin{tabular}{cc}
\hline & Coefficients \\
[Standard Errors]
\end{tabular}

(*) Refers to the hypothesis that the URR coefficient is equal to zero in the long-run equation.

\section{Table 8}

Error-Correction Model for Real Exchange Rate to Colombia (1993-2000)

\begin{tabular}{|c|c|c|c|c|c|}
\hline Variable & $\begin{array}{l}\text { Coefficient } \\
\text { [P-values] }\end{array}$ & R-squared & $\mathbf{L M}$ & White & Normality \\
\hline & & 0.284 & $\begin{array}{c}18.314 \\
{[0.11]}\end{array}$ & $\begin{array}{l}0.153 \\
{[0.70]}\end{array}$ & $\begin{array}{c}58.870 \\
{[0.00]}\end{array}$ \\
\hline Intercept & $\begin{array}{l}0.587 \\
{[0.06]}\end{array}$ & & & & \\
\hline$\Delta \mathbf{R E R}_{\mathrm{t}-1}$ & $\begin{array}{c}0.415 \\
{[0.00]}\end{array}$ & & & & \\
\hline$\Delta \mathbf{R E R}_{\mathrm{t}-2}$ & $\begin{array}{l}-0.310 \\
{[0.00]}\end{array}$ & & & & \\
\hline$\Delta$ Tax Equivalent $t_{t-1}$ & $\begin{array}{c}-0.011 \\
{[0.88]}\end{array}$ & & & & \\
\hline$\Delta$ Government Expenditure $_{t-1}$ & $\begin{array}{c}0.030 \\
{[0.10]}\end{array}$ & & & & \\
\hline$\Delta$ Government Expenditure $_{t-2}$ & $\begin{array}{l}0.021 \\
{[0.10]}\end{array}$ & & & & \\
\hline Error Correction Term & $\begin{array}{l}-0.051 \\
{[0.08]}\end{array}$ & & & & \\
\hline
\end{tabular}

LM refers to the Lagrange Multiplier test for serial correlation of the residuals of the model, White represents the White test for heterocedasticity of the residuals, Normality is the Jarque-Bera test for the normality of the residuals in the regression. P-values for all the test statistics are presented in brackets. 


\section{APPENDIX A}

Unit-Root Tests for Chilean Variables

\begin{tabular}{ccc}
\hline & ADF-GLS test statistic & Ng-Perron test statistic \\
\hline Net total Flows & $-1.949(* *)$ & $-2.297(* *)$ \\
Net Long-Term Flows & $-3.672(* * *)$ & $-5.318(* * *)$ \\
Net Short-term Flows & -0.800 & -0.919 \\
Trade Balance & $-4.324(* * *)$ & $-3.515(* * *)$ \\
Real Exchange Rate Gap & $-5.487(* * *)$ & $-5.419(* * *)$ \\
Tax Equivalent & -0.785 & -0.757 \\
World Oil Prices & $-2.755(* * *)$ & $-2.847(* * *)$ \\
Terms of Trade & $-1.879(*)$ & $-1.720(*)$ \\
Junk Bond Spread & $-2.198(* *)$ & $-2.205(* *)$ \\
Real Exchange Rate & -0.950 & -1.052 \\
Government Spending & -0.665 & -0.391 \\
Net Foreign Assets & -1.805 & -1.813 \\
Interest Differential & $-5.261(* * *)$ & $-5.061(* * *)$
\end{tabular}

$(* * *)$ Denotes significance at the $1 \%$ level $(* *)$ Denotes significance at the $5 \%$ level and $(*)$ significance at the $10 \%$ level. Lag selection based on Schwartz information criterion. All the variables were stationary in first-differences i.e. there were no I(2) variables.

\section{Unit-Root Tests for Colombian Variables}

\begin{tabular}{ccc}
\hline & ADF-GLS test statistic & Ng-Perron test statistic \\
\hline Net Total Flows & $-3.181(* * *)$ & $-2.911(* * *)$ \\
Net Long-Term Flows & $-7.228(* *)$ & $-4.976(* * *)$ \\
Net Short-Term Flows & -1.232 & -1.224 \\
Interest Differential & $-2.476(* *)$ & $-1.753(*)$ \\
Real Exchange Rate Gap & $-1.766(*)$ & $-9.634(* * *)$ \\
Trade Balance & $-2.202(* *)$ & $-2.108(* *)$ \\
Real Exchange Rate & -0.936 & -1.052 \\
Net Foreign Assets & -2.568 & -0.941 \\
Terms of Trade & -1.497 & -1.502 \\
Government Expenditures & -0.131 & 0.102 \\
Tax Equivalent & -1.330 & -1.307 \\
\hline
\end{tabular}

(***) Denotes significance at the $1 \%$ level $(* *)$ Denotes significance at the $5 \%$ level and (*) significance at the $10 \%$ level. Lag selection based on Schwartz information criterion. All the variables were stationary in first-differences i.e. there were no I(2) variables. 


\section{Appendix B}

\section{Changes in Taxes on Capital Inflows in Chile 1991-2001}

\begin{tabular}{|c|c|}
\hline & Changes in Capital Account Regulation \\
\hline June 1991 & $\begin{array}{l}\text { Unremunerated Reserve Requirement Imposed at } \\
\text { a Rate of } 20 \% \text {. Holding period equal to the } \\
\text { maturity of the credit up to } 12 \text { months. }\end{array}$ \\
\hline May 1992 & $\begin{array}{l}\text { Holding period set to } 12 \text { months \& URR } \\
\text { increased to } 30 \% \text { for bank credit lines. }\end{array}$ \\
\hline August 1992 & $\begin{array}{l}\text { URR increased to } 30 \% \text { \& Holding period fixed to } \\
12 \text { month, coverage of deposits extended. }\end{array}$ \\
\hline $\begin{array}{c}\text { January } 1995 \\
\text { July } 1995\end{array}$ & $\begin{array}{l}\text { Holding Currency Limited to USD only. } \\
\text { URR extended to secondary ADRs. }\end{array}$ \\
\hline October 1996 & $\begin{array}{l}\text { FDI committee to counter evasion and re- } \\
\text { labelling. }\end{array}$ \\
\hline June 1998 & URR reduced to $10 \%$ \\
\hline September 1998 & URR set to $0 \%$ \\
\hline June 2001 & Controls Eliminated. \\
\hline
\end{tabular}

Source: De Gregorio et al. (2000).

Changes in Taxes on Capital Inflows in Colombia: 1993-2000

\begin{tabular}{|c|c|}
\hline & Changes in Capital Account Regulation \\
\hline September 1993 & $\begin{array}{c}\text { Deposit Requirement of } 47 \% \text { applied to all } \\
\text { inflows of maturity under } 18 \text { months for a holding } \\
\text { period of } 12 \text { months. }\end{array}$ \\
\hline March 1994 & $\begin{array}{l}\text { Deposit extended to all inflows of less than } 36 \\
\text { months maturity. Borrowers given the option to } \\
\text { choose holding period and deposit rate varied } \\
\text { accordingly. Reserve requirements of } 93 \% \text { for } 12 \\
\text { month deposits, } 64 \% \text { for } 18 \text { months deposits and } \\
50 \% \text { for } 24 \text { months deposits. }\end{array}$ \\
\hline August 1994 & $\begin{array}{c}\text { Deposits extended to all foreign Loans with } \\
\text { Maturity of less than } 5 \text { years. Holding period } \\
\text { equal to the maturity of loan and deposit rates } \\
\text { vary from } 140 \% \text { for loans with maturity of less } \\
\text { than } 1 \text { month to } 42.8 \% \text { for loans with } 60 \text { months } \\
\text { maturity. }\end{array}$ \\
\hline March 1996 & $\begin{array}{l}\text { Controls relaxed. Deposit Requirement of 50\% } \\
\text { and holding period of } 18 \text { months imposed on } \\
\text { inflows with maturity of less than } 3 \text { years. }\end{array}$ \\
\hline March 1997 & $\begin{array}{l}\text { Deposit requirement extended to all flows with } \\
\text { less than } 5 \text { year maturity. }\end{array}$ \\
\hline May 1997 & $\begin{array}{l}\text { All capital inflows subject to } 30 \% \text { deposit in } \\
\text { Colombian Pesos with } 18 \text { month holding period. }\end{array}$ \\
\hline January 1998 & $\begin{array}{c}\text { Deposit Requirement Reduced to } 25 \% \text { and } \\
\text { Holding Period to } 12 \text { months. }\end{array}$ \\
\hline September 1998 & $\begin{array}{c}\text { Deposit reduced to } 10 \% \text { and holding period to } 6 \\
\text { months. }\end{array}$ \\
\hline June 2000 & Reserve Requirements Eliminated \\
\hline
\end{tabular}

Sources: Cardenas \& Barrera (1997), Rincon (1999), Central Bank of Colombia. 


\section{Appendix C}

\section{Overview of Data \& Sources}

\begin{tabular}{|c|c|c|}
\hline Series & Description/Notes & Source \\
\hline $\begin{array}{c}\text { Domestic } \\
\text { Interest Rate }\end{array}$ & $\begin{array}{c}\text { Colombia: 90-day Certificados de Deposito a Termino. } \\
\text { Chile: Until April } 1995 \text { PRBC } 90 \text { rate (indexed to } \\
\text { inflation) after May } 1995 \text { Overnight indexed interest } \\
\text { rate. }\end{array}$ & $\begin{array}{l}\text { Chilean Central Bank Website } \\
\text { (www.bcentral.cl) and } \\
\text { Colombian Central Bank Website } \\
\text { (www.banrep.gov.co). }\end{array}$ \\
\hline Trade Balance & Export of goods and services minus imports in Logs. & $\begin{array}{l}\text { Author's Calculations from raw } \\
\text { data of the respective Central } \\
\text { Banks. }\end{array}$ \\
\hline $\begin{array}{c}\text { Nominal } \\
\text { Exchange Rate }\end{array}$ & & $\begin{array}{l}\text { Chilean Central Bank Website } \\
\text { (www.bcentral.cl) and } \\
\text { Colombian Central Bank Website } \\
\text { (www.banrep.gov.co). }\end{array}$ \\
\hline $\begin{array}{c}\text { Forward } \\
\text { Exchange Rate }\end{array}$ & & $\begin{array}{l}\text { Colombian Central Bank Website } \\
\text { (www.banrep.gov.co). }\end{array}$ \\
\hline $\begin{array}{l}\text { Real Exchange } \\
\text { Rate }\end{array}$ & & $\begin{array}{l}\text { Chilean Central Bank Website } \\
\text { (www.bcentral.cl) and } \\
\text { Colombian Central Bank Website } \\
\text { (www.banrep.gov.co). }\end{array}$ \\
\hline $\begin{array}{l}\text { Real Exchange } \\
\text { Rate Gap }\end{array}$ & $\begin{array}{c}\text { Cyclical Component of Real Exchange Rate, obtained } \\
\text { by fitting a structural time series model (Kalman Filter) } \\
\text { to real exchange rate series. }\end{array}$ & Author's Calculations. \\
\hline $\begin{array}{l}\text { Country Risk } \\
\text { Premium }\end{array}$ & $\begin{array}{l}\text { Chile: premium on international bonds issued by } \\
\text { Chilean corporations. Colombia: Series constructed } \\
\text { using spread of Colombian bonds in international } \\
\text { markets over US T-bills. Updated using EMBI+ until } \\
2002\end{array}$ & $\begin{array}{l}\text { Central Bank of Chile, Rincon \& } \\
\text { Villar (2000) \& J.P. Morgan, } \\
\text { obtained from Thomson’s } \\
\text { Datastream. }\end{array}$ \\
\hline Terms of Trade & & $\begin{array}{l}\text { Bennett \& Valdes (2001) \& } \\
\text { Colombian Central Bank Website } \\
\text { (www.banrep.gov.co). }\end{array}$ \\
\hline $\begin{array}{c}\text { Government } \\
\text { Spending/GDP }\end{array}$ & & Gallego et al. (2002) \\
\hline $\begin{array}{l}\text { Real } \\
\text { Government } \\
\text { Spending }\end{array}$ & Deflated using Colombia's CPI. & $\begin{array}{l}\text { Colombian Central Bank Website } \\
\text { (www.banrep.gov.co). }\end{array}$ \\
\hline $\begin{array}{l}\text { Junk Bond } \\
\text { Spread }\end{array}$ & $\begin{array}{c}\text { Difference in Yields between US High-Yield Bonds and } \\
\text { 10-Year US Treasury Bonds. A number of different } \\
\text { High-Yield indexes where used such as Master II } \\
\text { (H0A0) and High Yield } 175 \text { (X0A0) }\end{array}$ & $\begin{array}{l}\text { Merrill Lynch, obtained from } \\
\text { Thomson’s Datastream. }\end{array}$ \\
\hline $\begin{array}{l}\text { World Oil Price } \\
\text { Index }\end{array}$ & & $\begin{array}{l}\text { IMF's International Financial } \\
\text { Statistics Database. }\end{array}$ \\
\hline US Interest Rate & 90-Day U.S. Treasury Bill & $\begin{array}{l}\text { IMF's International Financial } \\
\text { Statistics Database. }\end{array}$ \\
\hline $\begin{array}{l}\text { Net Foreign } \\
\text { Assets }\end{array}$ & & $\begin{array}{l}\text { IMF's International Financial } \\
\text { Statistics Database. }\end{array}$ \\
\hline $\begin{array}{c}\text { Interest Rate } \\
\text { Differential }\end{array}$ & $\begin{array}{l}\text { We experimented with a number of distinct differentials. } \\
\text { Generally calculated as difference between the reference } \\
\text { rate, the US interest Rate, the nominal exchange rate } \\
\text { devaluation (actual, past and forward rates were used } \\
\text { alternatively) and the country risk spread. }\end{array}$ & Author's Calculations \\
\hline
\end{tabular}




\footnotetext{
${ }^{\mathrm{i}}$ In mid-1995, for instance, the controls were extended, especially to secondary market ADRs and portfolio flows in order to close loopholes and make the regulations more restrictive Nonetheless, it is widely recognised in the literature that after those extensions FDI became a channel for the entrance of portfolio flows, which suggests an element of mere change of labels regarding the composition of flows. Despite this fact, there is no evidence that evasion of the capital account regulations was not merely marginal. Gallego et al. (2002) estimate that in the whole 1991-1998 period the total reserve deposit implied by the URR was on average $1.9 \%$ of Chile's GDP.

${ }^{\text {ii }}$ In order to obtain a rough estimate of the importance of U.S. capital flows to Chile, consider that bank loans from the U.S. amounted to $46 \%$ of total bank loans to Chile in 1994 according to BIS data and between 1990 and 1999 an average of 49.1\% of Chilean long-term debt was denominated in U.S. dollars according to World Bank's GDF data. In addition, $24.5 \%$ of total bank loans to Colombia originated in the U.S. in 1994 according to BIS data and 57.5\% of Colombia's total long-term debt was denominated in U.S. dollars on average during 1990-1999 period, according to the World Bank’s GDF dataset.

iii In addition, regarding the data on short-term flows, one has to note that "Banks include their liabilities and claims on foreign branches and other affiliates that arise out of normal banking business; brokers and dealers exclude items that represent inter-company balances. Also excluded from all respondents' reports are direct investments, positions arising from equity securities and debt issues with original maturity of more than one year, contingent items; and off-balance sheet contracts, including unsettled spot and forward foreign exchange contracts, options, and warrants" (see the TIC website at www.ustreas.gov). ${ }^{\text {iv }}$ Some authors tried to take into account the fact that players in financial markets will try to evade the regulations imposed and therefore the restrictions would "loose power" some time after implemented. De Gregorio et al. (2000) and Gallego et al. (2002) constructed an index that takes the value of 1 each time a new regulation is implemented (or the scope of previous regulations extended) and decays thereafter. The rate of decay chosen is purely arbitrary in those cases.

${ }^{v}$ The results reported are robust to different definitions of the tax equivalent.

${ }^{v i}$ The sample period was chosen to ensure that we use data over a single policy regime (to avoid structural breaks) and because of data availability.

vii Once again, the sample period was chosen because of data availability and to avoid structural breaks.

viii One has to bear in mind that it is important to estimate the co-integration relationships using data from a single macroeconomic policy regime, since it is likely that the parameters of the co-integration relationship would be unstable otherwise. There is a serious risk of inconsistency of estimates when the wrong cointegration relationships are imposed, since imposing wrong co-integration parameters will make the system converge to an incorrect equilibrium in the long run and also bias short-run dynamics.

${ }^{\text {ix }}$ In order to account for the move towards a floating exchange rate regime.

${ }^{\mathrm{x}}$ The critical values were 43.7 and 97.2 respectively, indicating rejection of the null hypothesis of no cointegration at the $5 \%$ level. The null of at most 1 co-integration relationship was not rejected (critical values 24.8 and 53.5).

${ }^{x i}$ The critical values were 42.9 and 91.1 respectively, indicating rejection of the null hypothesis of no cointegration at the $5 \%$ level. The null of at most 1 co-integration relationship was not rejected (critical values 22.9 and 48.1).
} 